Letter to the Editor

\title{
Massive retinal gliosis with episcleral extension
}

Bridget Copson MBBS(Hons), ${ }^{1}$ Penelope A McKelvie FRCPA ${ }^{2}$ and J wu J in Khong FRANZCO $\mathrm{PhD}^{3}$

1. Department of Surgery, Alfred Health, Melbourne, Victoria, Australia

2. Department of Anatomical Pathology, St Vincent's Hospital, Fitzroy, Victoria, Australia

3. Centre for Eye Research Australia, Royal Victorian Eye and Ear Hospital, Victoria, Australia

Correspondence: Dr J wu J in Khong, Centre for Eye Research Australia, Royal Victorian Eye and Ear Hospital, Peter Howson Wing, Level 7, 32 Gisborne Street East Melbourne 3002, VIC, Australia

Email: jwujinkhong@gmail.com

Received 1 February 2017; accepted 11 May 2017

Conflict of interest: None

Funding sources: None

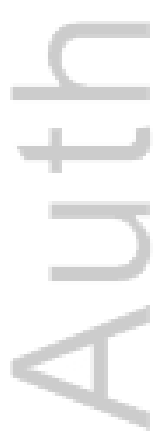

This is the author manuscript accepted for publication and has undergone full peer review but has not been through the copyediting, typesetting, pagination and proofreading process, which may lead to differences between this version and the Version of Record. Please cite this article as doi: $10.1111 /$ ceo.12989

This article is protected by copyright. All rights reserved. 
A 42 year old male presented with a two week history of red, painful and 'bulging' right eye. His past medical history included congenital toxoplasmosis resulting in bilateral microphthalmos, congenital blindness in the right eye and choroidal retinal lesions in the left eye with subsequent complete retinal detachment and loss of vision. The patient also had cerebral palsy, epilepsy and intellectual impairment secondary to congenital cerebral toxoplasmosis. There was no perception of light bilaterally. The right conjunctiva was injected with a large superior intraocular mass protruding anteriorly from the eye under the right upper eyelid (figure 1a). Bilateral corneal stromal opacities and vascularization, and hypopyon in the right eye were also noted. The right eye was tender to palpation.

Enucleation was recommended for diagnosis and treatment. An intra-operative $B$ scan confirmed an intraocular heterogeneous mass related to the superior aspect of the right globe. Intra-operatively, the right ocular mass was noted to be vascularised, pigmented, with overlying scleral thinning (figure $1 \mathrm{~b}$ ). The attachment of the superior rectus to the globe was splayed and displaced superiorly. The right eye was removed in total with an intact optic nerve stump, followed by a primary orbital implant insertion.

Histopathology revealed massive proliferation of astrocytes in the retina, completely replacing vitreous with focal extension superiorly into the sclera and epi-sclera (figure 2a). Focal hyalinisation of the blood vessel walls was present. Mild nuclear pleomorphism and occasional scattered multinucleated astrocytic giant cells but no mitoses were seen. The astrocytic proliferation extended up to the lamina cribrosa but not beyond. There was some nodular calcification and osseous metaplasia of the retinal pigment epithelium within the globe inferiorly. Immunohistochemistry showed strong diffuse reactivity for glial fibrillary acid protein (GFAP) and low Ki-67 proliferation index less than $1 \%$. Synaptophysin was negative. (Figure 2b). 
This case demonstrates massive retinal gliosis occurring in the context of congenital oculocerebral toxoplasmosis and is the first case in the literature to show extrascleral extension. Massive retinal gliosis refers to an extensive pseudoneoplastic proliferation of retinal glial cells. ${ }^{1}$ It is often associated with previous retinal damage such as trauma and retinal detachment ${ }^{1}$ as well as phthisis bulbi, congenital malformations and retinopathy of prematurity and neurofibromatosis-1..$^{1-3}$ Yanoff et al characterised massive gliosis of the retina by three histopathological features: 1 . overgrowth of glial tissue replacing the retina; 2 . abnormal blood vessels and 3. glial proliferation obliterating retinal architecture. ${ }^{1}$

Most recently, Jakobiec et al reviewed previous published cases and presented another 18 cases of intraocular gliosis and proposed a new classification of retinal tumoral gliosis with three categories, based on the degree of overgrowth and suggesting progression from: focal nodular gliosis, submassive gliosis to massive gliosis. ${ }^{4}$ The natural history of retinal gliosis was demonstrated in a case report by Hudson et al, left untreated, a focal nodular gliosis can progress to massive retinal gliosis. ${ }^{5}$ Massive retinal gliosis is the extreme spectrum of retinal gliosis where 50$100 \%$ of vitreous cavity is replaced by gliosis. ${ }^{4}$ The glial proliferation has the following histopathological and immunohistochemical features: compact spindled fibrous astrocytic proliferation, presence of hyalinised vessels, scattered hyperchromatic and irregularly shaped nuclei, positive GFAP and negative Alcian blue staining in the myxoid matrix in all cases. The majority were also positive for nestin, a neuro-ectodermal stem cell marker. Importantly the gliosis was non-neoplastic, with absence of immunohistochemical expression of tumour suppressor gene TP53, negative Ki-67 and intact p16. ${ }^{4}$ 
Our case is of specific interest as it demonstrates for the first time, scleral and episcleral extension in massive retinal gliosis. This represents an extension of the natural history of massive retinal gliosis.

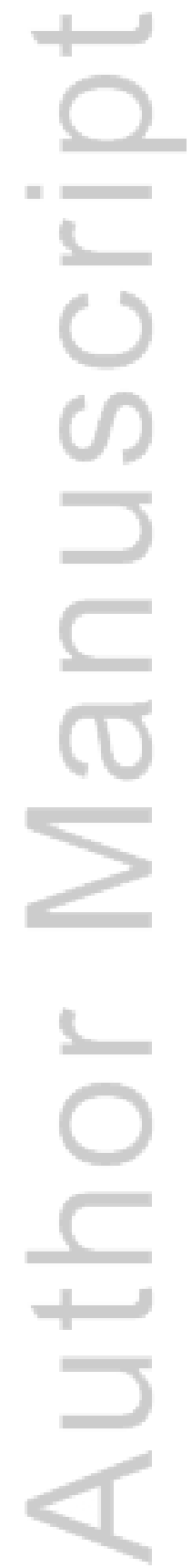

This article is protected by copyright. All rights reserved. 


\section{REFERENCES}

1. Yanoff M, Zimmerman LE, Davis RL. Massive gliosis of the retina. Int Ophthalmol Clin 1971; 11: 211-29.

2. Houston SK, Bourne TD, Lopes MB, Ghazi NG. Bilateral massive retinal gliosis associated with retinopathy of prematurity. Arch Pathol Lab Med 2009; 133:

\section{$1242-5$.}

3. - Jakobiec FA, Rashid A, Lewis K. Massive retinal gliosis in neurofibromatosis type 1. JAMA Ophthalmol 2015; 133: 100-2.

4. Jakobiec FA, Thanos A, Stagner AM, Grossniklaus HE, Proia AD. So-called massive retinal gliosis: A critical review and reappraisal. Surv Ophthalmol 2016; 61: 339-56.

5. Hudson LE, Mendoza PR, Yan J, Grossniklaus HE. Reactive Retinal Astrocytic Tumor (Focal Nodular Gliosis): A Case Report. Ocul Oncol Pathol 2017; 3: 17. 


\section{FI GURE LEGENDS}

Figure 1a: Pre-operative examination of right eye

Figure 1b: Intraoperative view of scleral mass

Figure 2a: high power magnification of retinal gliosis showing bland astrocytic cells . H\&E X400 magnification.

Figure 2b: Low power magnification of the massive retinal gliosis showing focal scleral and episcleral extension with GFAP immunohistochemistry. Magnification x100.

This article is protected by copyright. All rights reserved. 

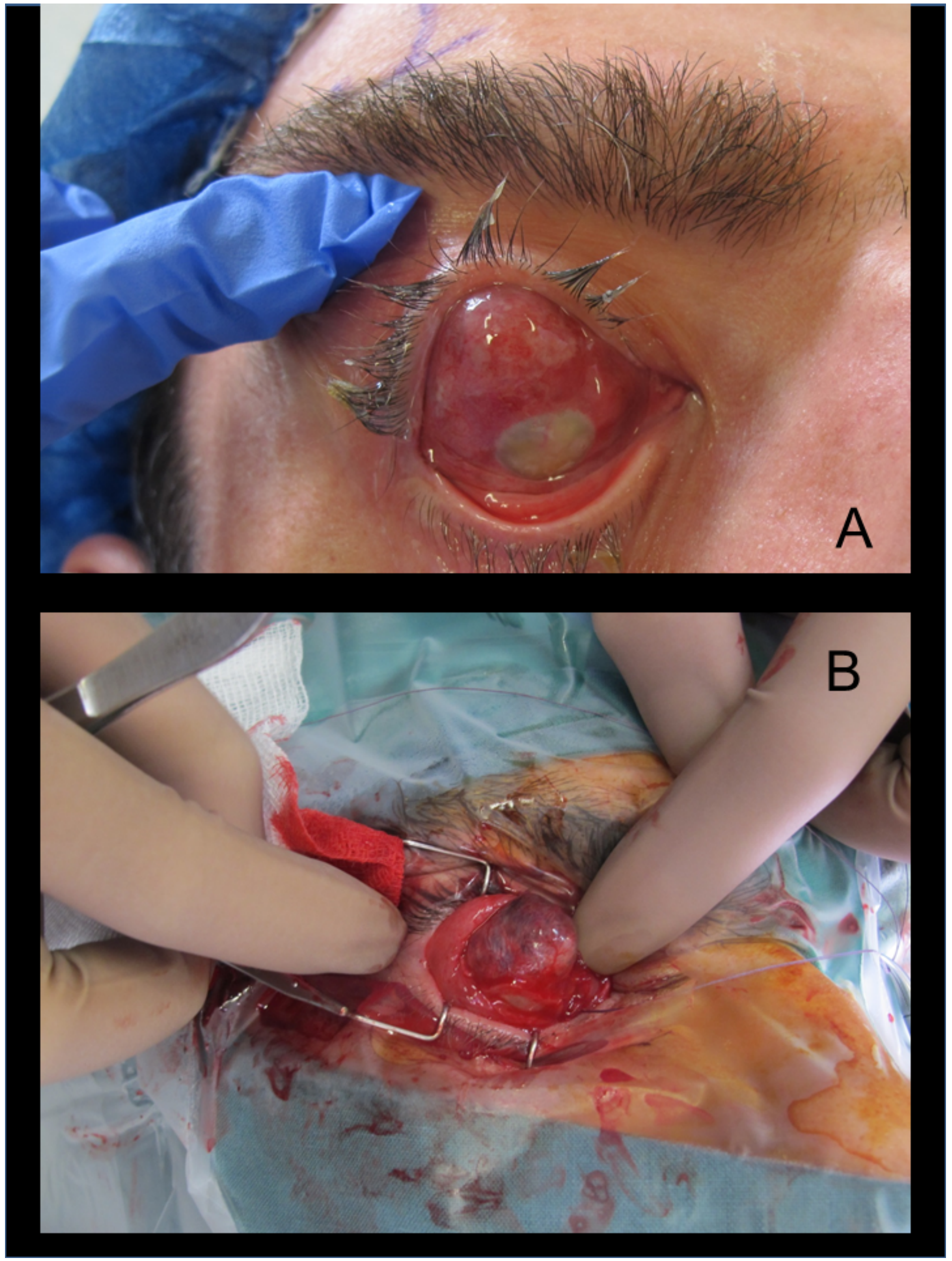

This article is protected by copyright. All rights reserved. 


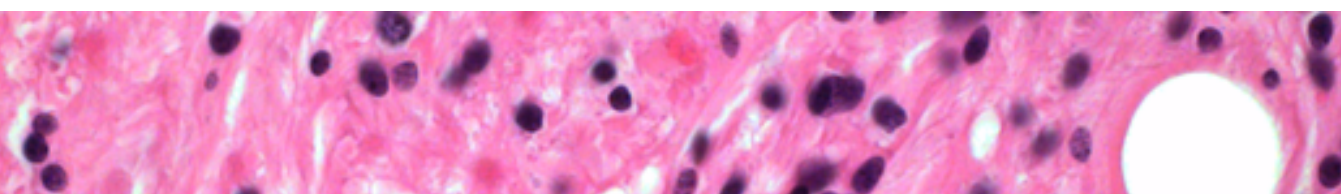

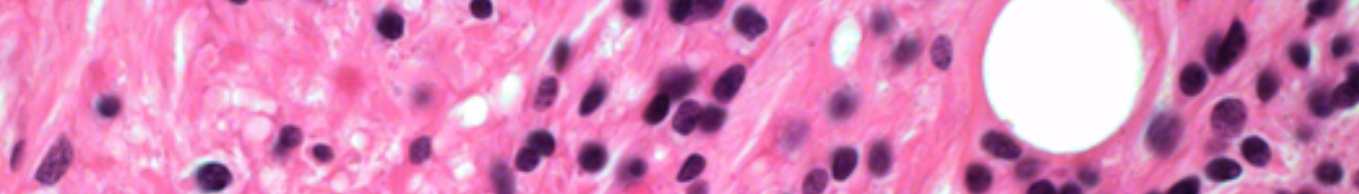

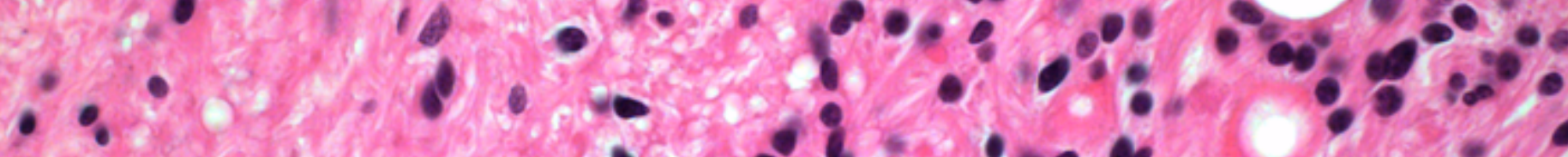

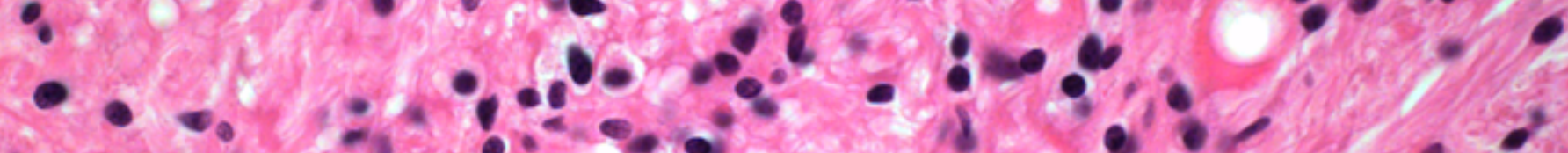

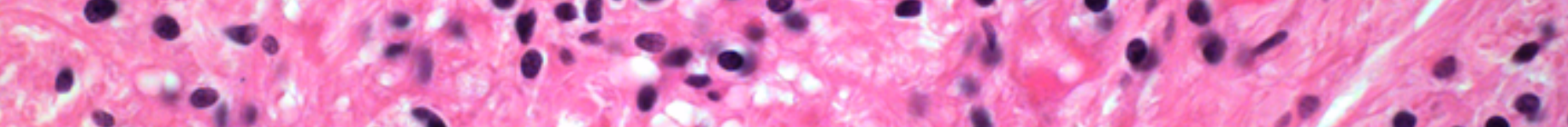
: : 1. il $\because 0.0,0 \%$

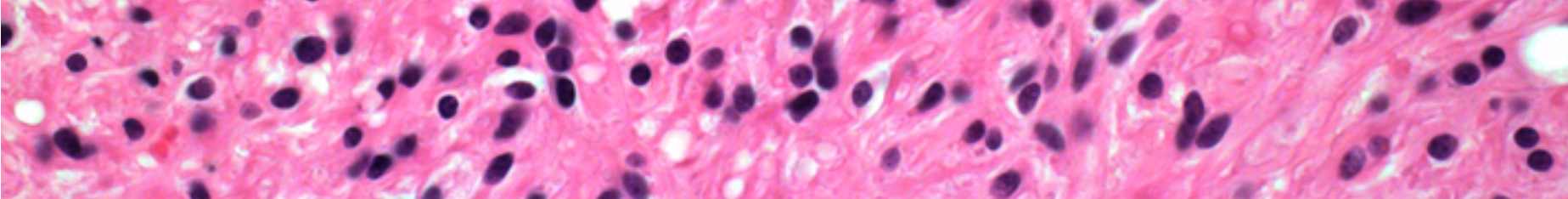

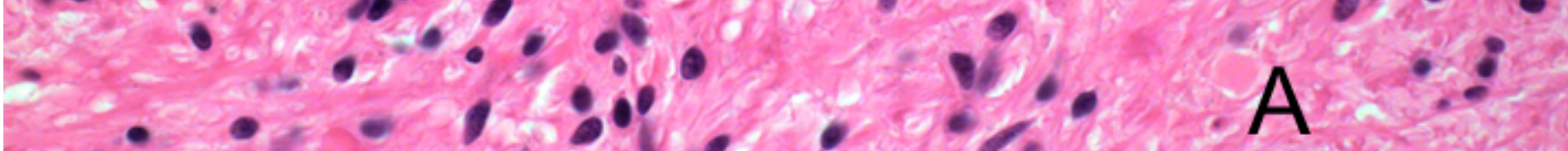

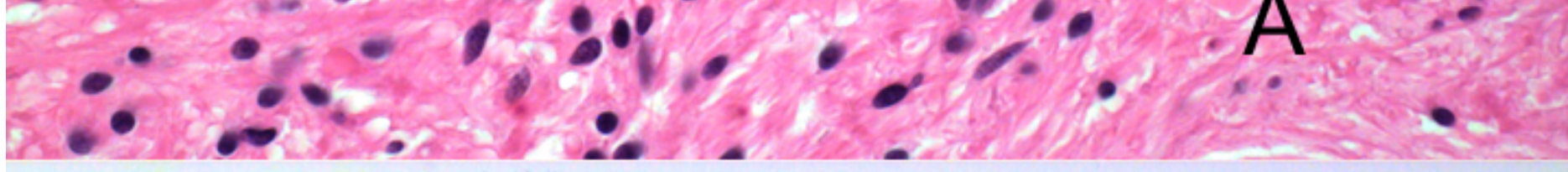

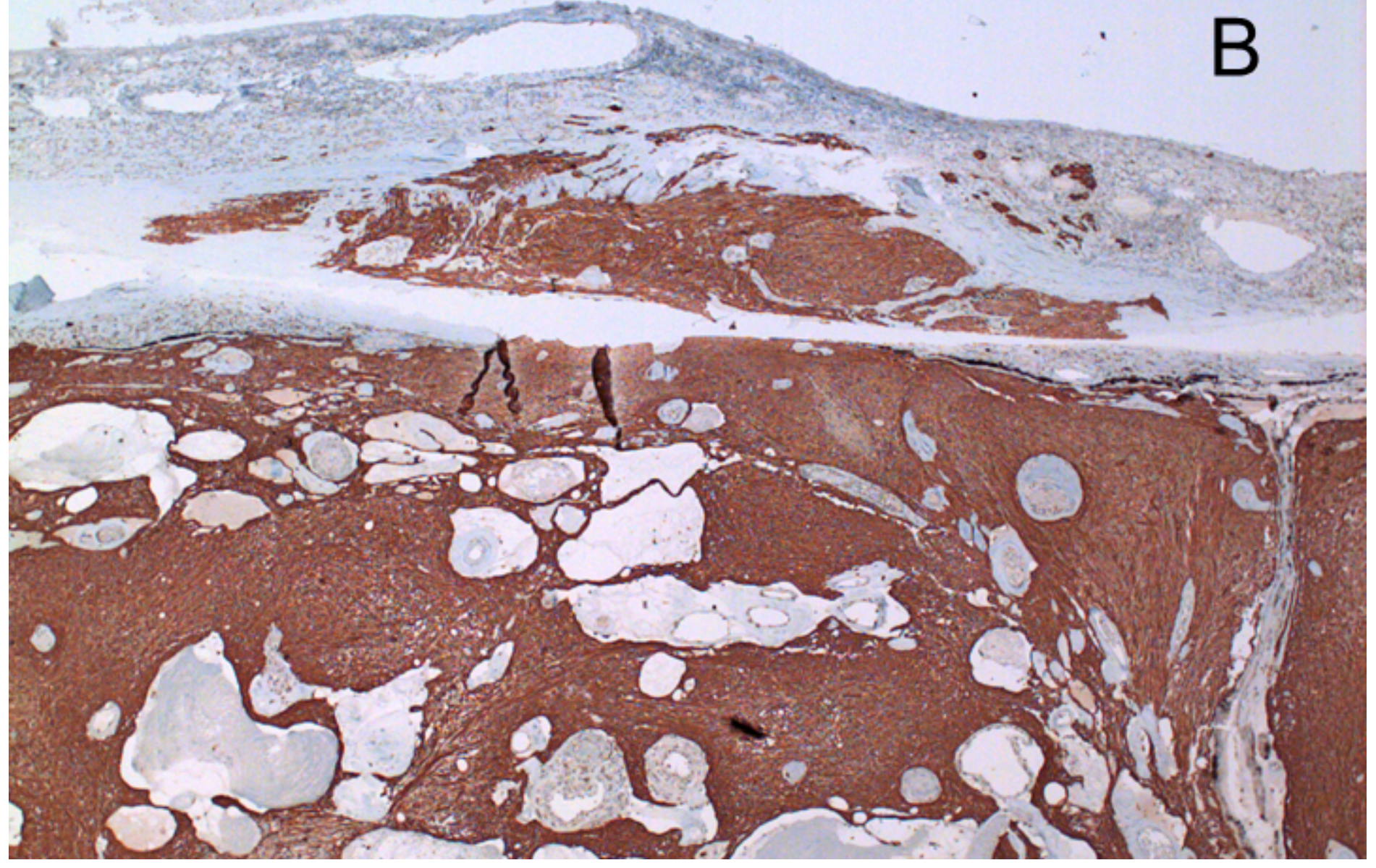




\section{University Library}

\section{- M M I E R R A A gateway to Melbourne's research publications}

Minerva Access is the Institutional Repository of The University of Melbourne

Author/s:

Copson, B;McKelvie, PA;Khong, JJ

Title:

Massive retinal gliosis with episcleral extension

Date:

2017-12-01

Citation:

Copson, B., McKelvie, P. A. \& Khong, J. J. (2017). Massive retinal gliosis with episcleral extension. CLINICAL AND EXPERIMENTAL OPHTHALMOLOGY, 45 (9), pp.923-924. https:// doi.org/10.1111/ceo.12989.

Persistent Link:

http://hdl.handle.net/11343/293038 